\title{
HISTOLOGIC ALTERATIONS OF THE BASEMENT MEMBRANE OF THE DERMAL AND EPIDERMAL LAYERS OF THE HOOF IN HORSES WITH ACUTE LAMINITIS
}

\author{
ALTERACIONES HISTOLÓgICAS DE LA MEMBRANA BASAL DE LAS CAPAS DÉRMICAS Y EPIDÉRMICAS DEL \\ CASCO EN LOS CABALlOS CON LAMINITIS AGUDA \\ "Rita de Cássia de Lima Sampaio; * Julio Carlos Canola; \\ **** José Corrêa de Lacerda Neto \&**Julieta Rodini Engrácia de Moraes
}

\begin{abstract}
SAMPAIO, L. R. C.; CANOLA, J. C.; LACERDA NETO, J. C. \& DE MORAES, E. J. R. Histologic alterations of the basement membrane of the dermal aand epidermal layers of the hoof in horses with acute laminitis. Int. J. Morphol., 22(4):307-312, 2004.

SUMMARY: The morphological characteristics of the hooves of two groups of horses were studied. The first group was comprised of six adult animals without any treatment and served as the control. The other group, comprised of seven horses, received carbohydrates overload orally. Of these, $71 \%$ developed laminitis between 36 and 48 hours after carbohydrate administration. After 48 hours of induction, the animals were sacrificed and their fore limbs and hindlimbs were removed for histologic study. Tissue sections 5 to $7 \mu \mathrm{m}$ thick were obtained, stained with hematoxylin-eosin (H\&E) or periodic acid Schiff's (PAS), and then examined by light microscopy. It was possible to identify in horses from the laminitis group, morphological and structural changes in the architecture of the primary and secondary epidermal lamellae, which were found to be sharpened and elongated with basal cells having round-shaped nuclei and also localized at the basal pole. PAS staining showed that in horses from the control group there were the presence of a basement membrane, separating and outlining the dermal and epidermal lamellae. In the laminitis group horses, there were deformation and fragmentation of the basement membrane. The utilization of PAS permitted the determination of the degenerative alterations in the basement membrane, which occurred early and coincident with the development of clinical signs of lameness.
\end{abstract}

KEY WORDS: 1. Basement membrane; 2. Equine; 3. Laminitis.

\section{INTRODUCTION}

The basement membrane found in the hooves of horses is essentially the same as in other animals, however with an important specialization. It is responsible for the union of the secondary dermal and epidermal lamellae, and consequently for the support of the whole axial skeleton. When this fine layer is somehow damaged, there is a dissociation of the dermal and epidermal lamellae resulting in laminitis.

There have been various hypotheses to explain the development of digital circulatory failure in horses at the onset of laminitis. These are based on possible effects induced by endotoxins in the lamellar blood flow, such as microthrombosis, vasoconstriction, perivascular edema or the shunts of blood flow by arteriovenous anastomosis (Moore \& Allen, 1996).

Morphologic studies of laminitis have focused on modifications occurring from the time of observed lameness up to $72 \mathrm{~h}$ afterward. Some observations have described changes present before or coincident with the onset of lameness (Hood et al., 1993). Histologic alterations are observed in the blood vessels of the digital circulation. Anatomic distortions of the lamellae occur only $8 \mathrm{~h}$ after lameness. There is a thinning and sharpening of the lamellar structures accompanied by reduction, smoothening and dislocation of the epithelial layers (Obel, 1948; Mostafa, 1986; Pollitt, 1996).

\footnotetext{
* Cirurgia Veterinária, Faculdade de Ciências Agrárias e Veterinárias/ Universidade Estadual Paulista, Jaboticabal, SP., Brasil.

** Departamento de Patologia Veterinária, FCAV/UNESP, Jaboticabal, SP., Brasil.

**** Departamento de Clínica e Cirurgia Veterinária, UNESP, Jaboticabal, SP., Brasil.

Fundação de Amparo à Pesquisa do Estado de São Paulo (FAPESP) - (Processo n. 00/10308-2).
} 
Histologic alterations present in the distal digit of the horse with acute laminitis reflect the occurrence of three processes: angiopathy, mechanical distortion of the dermalepidermal tissues and physiopathologic response in these tissues with angiopathy preceding the other two (Baxter, 1994).

The observed alterations in the epidermal lamellae of horses with acute laminitis have been classified according to the severity of the lesions (Pollitt, 1996). This classification system is based principally on the alterations of the basement membrane (BM) of the lamellae. The histopathologic system of classification correlated adequately with the degree of lameness, at the time of sacrifice, and apparently described accurately the severity of the laminitis. The disintegration of the BM and its loss of attachment to the basal cells of the epidermis are the earliest pathologic events in acute laminitis and can be the alterations that give rise to the collapse of the lamellar architecture.

The BM is comprised of collagenous proteins, such as type IV collagen, and non collagenous proteins, such as proteoglycans and glycoproteins, of which the main one is laminin. This undergoes enzymatic degradation through the action of metalloproteinases. There is a possibility that uncontrolled activation of metalloproteinase is an important and early event in the pathogenesis of equine laminitis (Pollitt et al., 1998). Metalloproteinases activated by low-molecular weight molecules give rise to laminitis, and the formation of microthromboses occur secondarily and/or concomitantly with lesions of the BM (Pollitt, 1996; Pollitt \& Davies, 1998).

Streptococcus bovis, in the prodromic phase of laminitis, could be responsible for the release of substances that activate metalloproteinase (Johnson, 1998; Pollitt \& Davies).

In view of the importance of laminitis in horse breeding stocks with significant losses of animals of high breed and economic value, and because the alterations in the dermal and epidermal structures play a key role in the development of this affliction, the aim of this study was to examine the histologic changes developed 48 hours after the induction of laminitis, focusing on the changes occurring at the basement membrane of the dermal and epidermal lamellae of the hoof.

\section{MATERIAL AND METHOD}

Thirteen adult mixed breed healthy mature horses were utilized. The animals were housed in individual stalls in the Experimentation Section of the Research Laboratory of the Department of Clinical and Surgical Veterinary Medicine at FCAV/UNESP. The horses were confined for a period of two weeks to allow adaptation to the new environment. Daily feed was comprised of $2.0 \mathrm{~kg}$ of concentrated ration, furnished one time per day, in addition to hay water and mineral salts provided ad libitum. At the end of the adaptation period, the animals were distributed randomly into two groups:

Group I was comprised of six healthy horses, which were to be, for humanitarian and economic reasons, submitted to euthanasia. The animals received no treatment and were followed clinically and by laboratory tests for a period of 48 hours, at which time they were sacrificed and after euthanasia, distal extremities of the four limbs were disarticulated at the metacarpo-phalangeal and metatarso-phalangeal joints, for the forelimbs and hindlimbs, respectively. (Control).

Group II was comprised of seven horses. After an overnight fastening of 12 hours, acute laminitis was induced by carbohydrate overload of the alimentary tract as described for Garner et al. (1975). The animals were followed clinically and by laboratory tests for $48 \mathrm{~h}$. This group of horses did not receive any treatment after induction of laminitis. (Laminitis).

The hooves were sectioned with a band saw, according to the protocol described for Pollitt (1996). At the end of the procedure a rectangular fragment of dermal-epidermal tissues was obtained, with the sides measuring $1.0 \times 0.5 \mathrm{~cm}$ and a thickness of $0.1 \mathrm{~cm}$, and containing the junction between the dermal and epidermal lamellae. These specimens were fixed in $10 \%$ formalin, dehydrated with alcohol and embedded in paraffin. Sections of 5 to $7 \mu \mathrm{m}$ thick were stained with hematoxyin-eosin (H\&E) and periodic acid Schiff (PAS) and then examined by light microscopy.

\section{RESULTS}

The development of lameness was observed in $71 \%$ of the horses in the laminitis group between 36 and 48 hours after carbohydrate administration. Upon histologic examination, changes were seen in all the animals in this group.

Examination of the H\&E stained hoof tissue in horses of the control group, revealed the structure and disposition of the dermal and epidermal lamellae. The primary epidermal lamellae (PEL) originate from the internal portion of the horny stratum of the hoof wall, projecting in the direction of the distal phalanx. They are composed of keratin, non tubular in composition. The toothed appearance of the surface of the PEL is conferred by the secondary epidermal lamellae (SEL). The space between the primary and secondary lamellae is filled by the loose connective tissue constituting the primary and 
secondary lamellae. At high magnification (600x), the periphery of the secondary epidermal lamellae can be seen to be lined by a single layer of cylindrical cells with oval nuclei, called basal cells (Fig. 1A).

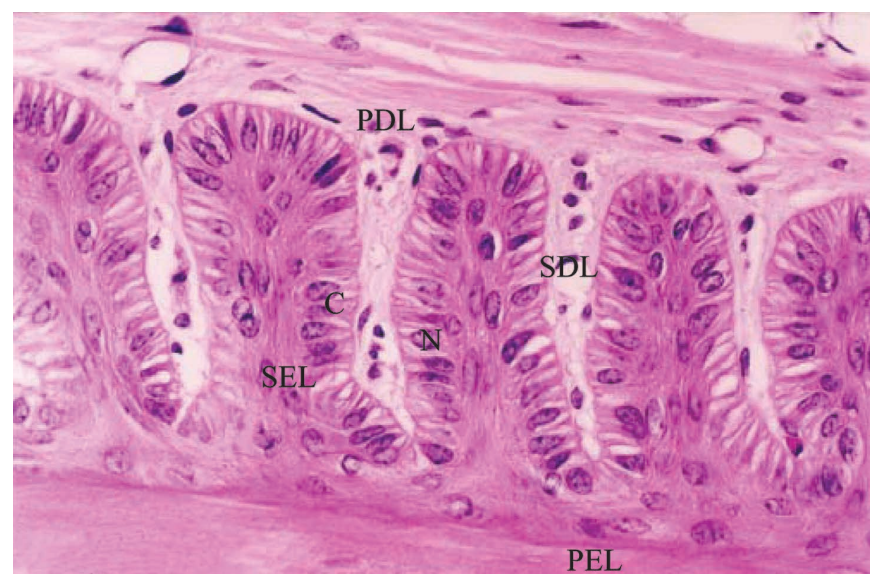

Fig. 1A. Histologic appearance of the dermal and epidermal lamellae of hooves of control horses, demonstrating the difference in width between SEL and SDL, the club-shape of the SEL, presence of keratocyes in the SEL, and nuclei at the apex of the basal cells (BC). HE. 600x.

PAS staining showed that at the junction of the dermal and epidermal lamellae, there was a structure of extracelullar matrix, called the basement membrane $(\mathrm{BM})$, which stains magenta and penetrates deeply the crypts between the surrounding SEL, outlining the pointed tip of each secondary dermal lamellae (SDL). On the other hand, the BM of horses in the control group was found to be intact and clearly delineated, without any interruptions or blurring. It outlined the tips of the SEL which are in the shape of projections, like the fingers of a glove, invariably rounded and never sharpened or tapered (Fig. 1B).

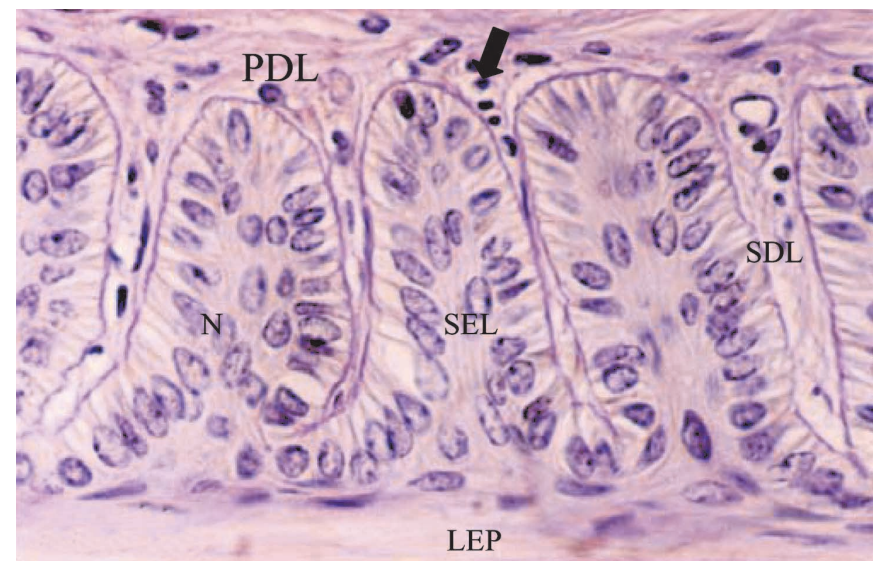

Fig. 1B. Histologic appearance of the dermal and epidermal lamellae of hooves of control horses, showing the basement membrane stained magenta and clearly outlining the SEL and penetrating deeply between the crypts of the SDL, the SDL well attached to the BM, the glovefinger shape of the SEL, and oval nuclei at the apex of the basal cells (BC). PAS. 600x.
The tissue changes observed in the H\&E stained sections, in the horses of the laminitis group, indicated straightening and elongation of the SEL with tapered tips, in addition to being variable sizes and having irregular positioning. The symmetry of the lamellae had disappeared. In sections where the lesions were more serious, there was loss of lamellar architecture at the apical pole of the PEL and congestion of the blood vessels and capillaries, and the tips of the PEL were sharpened and contracted. At higher magnification, it was seen that the majority of the nuclei of the basal cells were rounded and displaced toward the basal pole. The $90^{\circ}$ angle between the major diameter of these nuclei in relation to the keratinized axis of the SEL had been lost. The secondary dermal lamellae were found to be retracted. Thecentral axis of the SEL was identified only as distinct architectural entities. Many of the epidermal cells formed an amorphous mass alternating between the PDL and PEL (Fig. 2A).

In the horses of the laminitis group, the PAS stained sections had deformities in the dermal and epidermal lamellae in general, with the apparent separation of the SEL from the BM. The BM was wavy and had an irregular shape with a serrated and blurred appearance. At the base of many SEL, the BM was absent and the SEL were attached to each other. The SEL localized at the apex of the PEL were empty, that is, the basal cells had disappeared, with only the original outline conferred by the BM remaining, appearing like fingers of a glove. The tips of the SEL had shapes that were sharper or more pointed. In more serious lesions, the distance between the $\mathrm{BM}$ and the border of the keratinized axis of the PEL increased from two basal cells to three or four. The tips of the PEL were devoid of epidermal cells and consisted almost entirely of PAS-positive BM. The staining was particularly dense where two layers of BM of the collapsed tubes were side by side. The absence of BM in many SEL was observed. Several SEL were attached to each other without the presence of BM between them, and the BM outlined all the SEL at the same time as a straight line without invaginations (Fig. 2B).

\section{DISCUSSION}

The findings reported in this study are consistent with previous observations indicating the presence of fibrillar material in the tips of the PEL in HE stained sections. Studies carried out by various authors detected the presence of empty spaces between the basal cells of the SEL and the BM, which provided evidence of edema, possible due to the increase in capillary hydrostratic 


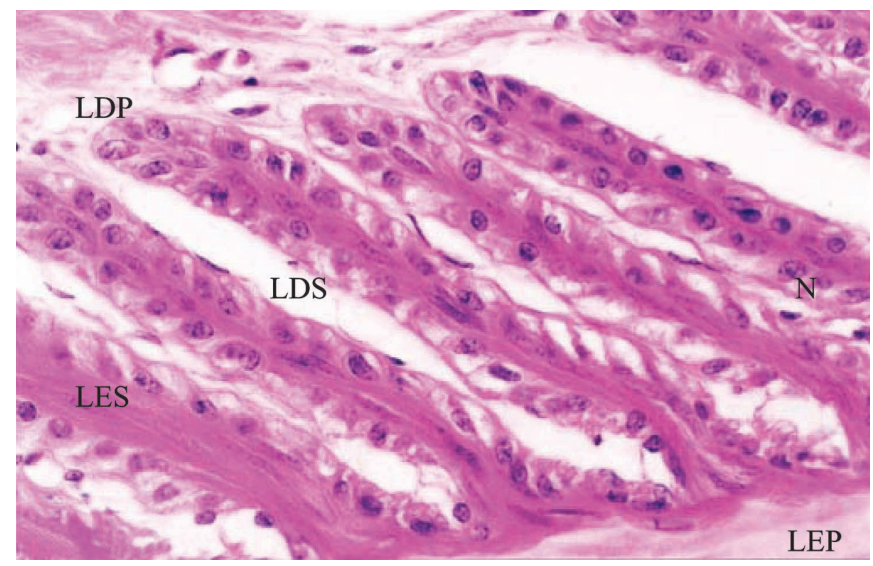

Fig. 2A. Histologic appearance of the dermal and epidermal lamellae of hooves of laminitis horses, showing the morphologic alterations indicative of the laminar degenerative process. HE. 600x.

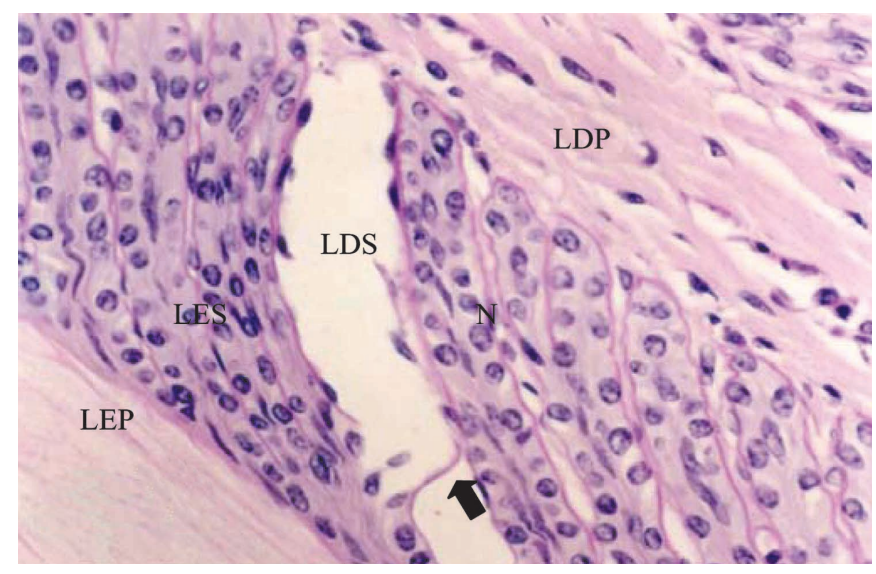

Fig. 2B. Histologic appearance of the dermal and epidermal lamellae of hooves of laminitis horses, showing the basement membrane stained magenta with serrated-appearing shape, straightening of the SEL and tapering of their tips, detachment of the SDL from the BM, nuclei at the apex of the basal cells (BC) are rounded. PAS. 600x.

pressure (Baxter; Garner et al.; Roberts et al., 1980). Meanwhile, studies utilizing PAS staining correlated the fibrillary residues and the empty spaces between the SEL and the $\mathrm{BM}$ to pieces of fragmented $\mathrm{BM}$ and to the retraction of the dermal lamellae, however without the presence of fluid (Pollitt, 1996). According to the author, these spaces could be filled with gases or air and be responsible for the appearance of a radioluscent line found in radiographs of hooves with acute laminitis. Other authors (Robinson et al., 1976) did not find any differences between control and induced horses in the concentration of lymphatic proteins, concluding that there was no support for the occurrence of edema.

The lamellar lesions of the BM, which is a clinical phenomenon that characterizes the onset of laminitis, occurred early in this study, and in the majority of cases only $6 \mathrm{~h}$ after the start of lameness. Although some authors affirm the importance of vasoconstriction in the development of the initial lesions of the affliction (Hood et al.), the origin of laminitis is still controversial (Pass et al., 1998). It is believed that ischemia could be a primary event and that hemodynamic changes could be occur secondary or parallel to the initial lesions of laminitis (Pollitt, 1999).

Histopathological studies of the hooves of horses with laminitis have indicated that the initial lesions occur at the BM, and when they undergo degeneration there is separation between the hoof wall and the distal phalanx. Several hypotheses have been put forth to explain the physiopathology of laminitis (Obel). Among these innumerable hypotheses formulated to elucidate the pathology of this affliction are those that argue the occurrence of vasoconstriction (Hood et al.) or the formation of thromboses and consequently deviation of blood flow by arteriovenous anastomoses (Robinson et al.; Trout et al., 1990) as the cause of diminished laminar perfusion.

Other investigators suggest that a decrease in circulation in the hoof lamellae occurs due to capillary constriction (Baxter) or in the formation of microthromboses in the blood vessels located in the dermis. Vascular constriction could be caused by the direct or indirect action of endotoxins (Sprouse et al., 1987).

PAS staining proved to be superior to H\&E staining for the visualization of the BM. This structure, which is extremely resistant, is the juncture between the basal cells of the epidermal lamellae on one side and the fine fibrous connective tissue (collagen type I) of the dorsal surface of the distal phalanx on the other. The integrity and marginal disposition of the $\mathrm{BM}$ is key in indicating lesions of the dermal and epidermal lamellae (Pollitt, 1996). Through PAS staining various alterations were observed in this structure, such as interruptions and/or fragmentation, and apparent loss of collagen in the BM. It was also possible to note the separation of the BM from the basal cells of the SEL, allowing the visualization of the apparently empty space between the BM and SEL.

The causes responsible for the alterations in BM are still speculative, as there are innumerable mechanisms by which the damages could occur. There is strong evidence that laminitis could be preceded by a metabolic crisis (Pass et al.). It was demonstrated that microvascular thrombosis occurs in horses with laminitis induced by carbohydrates and that the occurrence of systemic coagulopathy is prior to the initiation of claudication (Weiss et al., 1994). The latter is proved the elevated concentration of plasmin which gives rise 
to fibrinolysis. In addition to its fibrinolytic action, plasmin is a known activator of collagen IV and can activate the destruction of the lamellar BM by metalloproteinases. Moreover, the alterations in the BM could be triggered by tumor necrosis factor (TNF) which is found in high concentrations. Horses with gastrointestinal alterations have elevated plasma concentrations of TNF (May et al., 1992; Tracey et al., 1989).

In our study, a significant number of animals in the induced group developed diarrhea and coloration changes in the conjunctiva and oral mucosa, in addition to signs of dehydration. This could induce the production of collagenase in tissues and consequently destroy the integrity of the BM. Although innumerable hypotheses have been formulated with the aim of determining the mechanisms responsible for laminitis, there is still controversy over the true causes of the process. Still, the early occurrence of alterations in the $\mathrm{BM}$ is indisputable, as affirmed by the findings of the present investigation, making it possible to develop new experimental procedures with the aim of elucidating the factors responsible for this degeneration.

SAMPAIO, L. R. C.; CANOLA, J. C.; LACERDA NETO, J. C. \& DE MORAES, E. J. R. Histologic alterations of the basement membrane of the dermal aand epidermal layers of the hoof in horses with acute laminitis. Int. J. Morphol., 22(4):307-312, 2004.

RESUMEN: Fueron estudiadas las características morfológicas de los cascos de dos grupos de equinos. El primer grupo, conformado por cinco animales adultos, sin ninguna alteración clínica, correspondió al grupo control. El siguiente grupo, constituido por siete equinos recibieron $17,6 \mathrm{~g} / \mathrm{kg}$ de carbohidratos por vía oral, para la inducción de laminitis. De este grupo, $71 \%$ desarrolló la sintomatología entre 36 y 48 horas después de la administración del carbohidrato. Pasadas 48 h de la inducción de laminitis, los animales fueron sacrificados y sus miembros fueron retirados para realizar los respectivos estudios histológicos. Se efectuaron cortes histológicos de 5 a $7 \mu \mathrm{m}$ de grosor y, posteriormente, se tiñeron con hematoxilina-eosina (HE) y ácido peryódico de Schiff (PAS) para ser sometidos a microscopía óptica. A través de la coloración de HE, fue posible determinar alteraciones en la arquitectura de las láminas epidérmicas primarias y secundarias, las cuales se presentaron delgadas y anchas, con los núcleos de las células basales de forma arredondada y, eventualmente, localizados en su polo basal. La coloración por el PAS, permitió observar la membrana basal y la matriz proteica, separando las láminas epidérmicas y dérmicas y definiendo la morfología de éstas. En los equinos del grupo con laminitis se observaron deformación y fragmentación de la membrana basal. La utilización del PAS permitió determinar las alteraciones degenerativas graves en la membrana basal, de presentación precoz y coincidiendo con el desarrollo de los signos clínicos de claudicación.

PALABRAS CLAVE: 1. Membrana basal; 2.Equinos; 3. Laminitis.

\section{REFERENCES}

Baxter, G. M. Acute laminitis. Vet. Clin. North Am., 3:62742, 1994.

Garner, H. E.; Coffman, J. R.; Hann, A. N. et al. Equines laminitis of alimentary origin: an experimental model. Am. J. Vet. Res. 36(4):441-4, 1975.

Hood, D. M.; Grosenbaugh, D. A.; Mostafa, M. B. et al. The role of vascular mechanisms in the development of acute laminitis. J. Vet. Int. Med. 7(4):228-34, 1993.

Johnson, P. J. et al. Activacion of extracellular matrix metalloproteinases in equine laminitis. Vet. Rec. 142(15):392-6, 1998.

May, S. A.; Spiers, S.; Carter, S. D. et al. Identification of tumor necrosis factor in the blood and peritoneal cavity of horses with colic. Equine Vet. J., Suppl., 13:19-21, 1992.
Moore, J. N. \& Allen, D. The pathophysiology of acute laminitis. Vet. Med. october:936-9, 1996.

Mostafa, M. B. Studies on experimental laminitis in horse. Thesis. Universidade do Cairo, College of Veterinary Medicine, 1986.

Obel, N. Studies on the histopathology of acute laminitis. Almiquist and Wiksells, Uppsala, 1948.

Pass, M. A.; Pollitt, S. \& Pollitt, C. C. Decreased glucose metabolism causes separation of hoof lamellae in vitro: a trigger for laminitis? Equine Vet. J. Suppl., 26:133-8, 1998.

Pollitt, C. C. Basement membrane pathology: a feature of acute equine laminitis. Equine Vet. J. 28(1):38-46, 1996. 
Pollitt, C. C. \& Davies, C. T. Equine laminitis: its development coincides with increased sublamellar blood flow. Equine Vet. J. Suppl., 26:125-32, 1998.

Pollitt, C. C.; Pass, M. A. \& Pollit, S. Batismat (BB-94) inhibits matrix metalloproteinases of equine laminitis. Equine Vet. J. Suppl. 26:119-24, 1998.

Pollitt, C. C. A revised pathophysiology. Am. Assoc. Equine Pract. Proc. 45:188-92, 1999.

Roberts, E. A.; Ocha, R. \& haynes, P. R. Correlation of dermal-epidermal laminar lesions of equine hoof with various diseases conditions. Vet. Pathol., 17:656-66, 1980.

Robinson, N. E.; Jones, G. A.; Scott, J. B. et al. Digital vascular responses and permeability in equine alimentary laminitis. Am. J. Vet. Res., 37:1171-4, 1976.

Sprouse, R. F.; Garner, H. E. \& Green, M. E. GREEN ME Plasma endotoxin levels in horses subjected to carbohydrate induced laminitis. Equine Vet. J., 19(1):25$8,1987$.

Tracey, K. J.; Vlassara, H. \& Cerami, A. Cachectin/tumour necrosis factor. Lancet, 1122-6, 1989.
Trout, D. R.; Hornof, W. J.; Linford, R. L. et al. Scintigrafic evaluation of digital circulation during the developmental and acute phases of equine laminitis. Equine Vet. J., 22(6): 416-21, 1990.

Weiss, D. J.; Geeor, R. J.; Johnston, G. et al. Microvascular thrombosis associated with the onset of acute laminitis in ponies. Am. J. Vet. Res. 55:606-12, 1994.

Correspondence to:

Prof. Dra. Rita de Cássia de Lima Sampaio

Departamento de Clinica e Cirurgia Veterinária,

Via de Acesso Prof. Paulo Donato Castellane, $s / n$,

$\mathcal{F C A V / U \mathcal { E S P }}$

CEP 14.880-900

Jaboticabal, SP.

BRASIL

Fone: (016) 3209-2626.

Fax: (016) 32024275.

E-mail:jlacerda@fcav.unesp.br

Received : 27-07-2004

Accepted: 07-10-2004 